\title{
Integration of seismic, well, potential-field and geological data for ore prospecting in the Iberian Pyrite Belt
}

\author{
João Carvalho $^{\mathrm{a}, \mathrm{c}^{*}}$, Pedro Sousa ${ }^{\mathrm{b}}$, João Xavier Matos ${ }^{\mathrm{b}}$, Carlos Pinto $^{\mathrm{a}}$ \\ ${ }^{a}$ Laboratório Nacional de Energia e Geologia, Apartado 7586, 2721-866 Amadora, Portugal \\ ${ }^{\mathrm{b}}$ Laboratório Nacional de Energia e Geologia, Apartado 104, 7801-902 Beja, Portugal \\ ${ }^{\mathrm{c}}$ Centro Geofísica de Évora, Colégio Luís António Verney, 7000 Évora, Portugal \\ * corresponding author
}

\begin{abstract}
Summary
Ore prospecting using gravimetric and magnetic data has become one of the traditional approaches in the last decades, often complemented with electric and electromagnetic methods. However, due to the problem of non-uniqueness inherent to potential-filed modelling, constrains provided by structural methods such as seismic reflection are often used. During the exploration of massive sulphide polimetallic minerals in the Iberian Pyrite Belt Figueira de Cavaleiros sector, located in the Sado Tertiary Basin, several gravimetric and magnetic anomalies were considered as interesting targets. In order to reduce ambiguity of the gravimetric modelling and to confirm the geological model of the area, two seismic reflection profiles were acquired. The interpretation of these profiles was assisted by three mechanical boreholes, two of them located in the research area, in order to make a seismostratigraphic interpretation. Unfortunately, the gravimetric modelling suggests that the anomaly has a lithological and structural origin and is not related with massive sulphides. Nevertheless, a good agreement between the seismic and potential-field data was achieved and new insights into the geological model for the region were obtained form this work, with accurate data about the Tertiary cover and Palaeozoic basement.
\end{abstract}




\section{Introduction}

The area of Ferreira do Alentejo in Portugal is located in the Iberian Pyrite Belt (IPB), which is part of the South Portuguese Zone geological terrain (SPZ). The IPB is a base metals metallogenetic province characterized by having $\sim 90$ polymetallic massive sulphides ore bodies/deposits. IPB ores are being intensely explored since the $19^{\text {th }}$ century, and with more intensity after the Neves Corvo world class volcanogenic massive sulphide (VMS) deposit discovered in 1977, using gravity surveys (see Oliveira et al. 1998a, Carvalho et al. 1999, Oliveira et al. 2005, Relvas et al. 2006, Matos \& Martins 2006).

Indeed, potential methods (gravity and magnetic) have been important exploration tools and are commonly used along IPB with significant success in Portugal, responsible by the discovery of several orebodies (e.g. Neves-Corvo, Lagoa Salgada, Salgadinho, Estação and Gavião, Oliveira et al. 1998a, Carvalho et al. 1999). However, the results of modelling are an ill-posed problem and no unique solution exists. In structural complex areas this ambiguity is even larger and the seismic reflection method is often used for providing structural information and reducing the ambiguity of potential-field modelling.

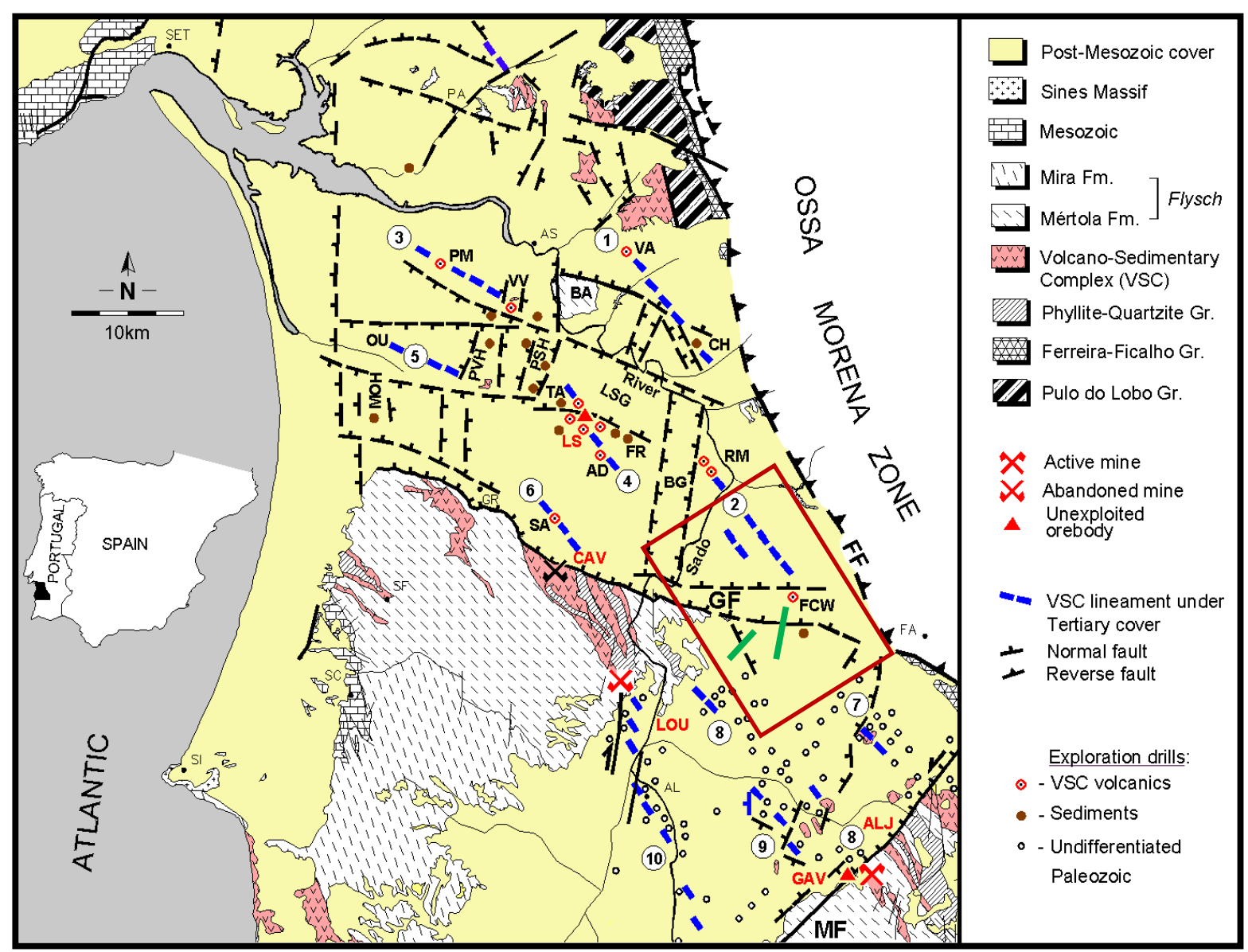

Figure 1 Geological setting of the study area (adapted from Oliveira et al., 2001; 2006a). Volcano-Sedimentary Complex structures of the Iberian Pyrite Belt NW sector: 1 - Vale Agua/Chaparral; 2 - Rio Moinhos/Figueira de Cavaleiros; 3 - Porto de Mel/Valverde; 4 - Lagoa Salgadal Água Derramada; 5 - Outeirão/Pedrógão; 6 Salgueiral; 7 - Lagoas do Paço/Ervidel; 8 - Carregueira/Furadouro; 9 - Nabos/Milhouros/Aljustrel; 10 Lousal/Alvalade. Grabens: BG - Batão, LSG - L. Salgada Norte. Horsts: MOH - Martim Afonso/Outeirão; PVH - Pedrógão/Valverde; PSH - Puigada/Monte Sobral. Faults: GF - Grândola; MF - Messejana; FF Ferreira-Ficalho. Ore sulfur deposits: LS - Lagoa Salgada, LOU - Lousal, CAV - Caveira, ALJ - Aljustrel. Gravity/magnetic survey areas: red color rectangle. Seismic profiles - green color lines.

In this paper we describe the massive sulphides exploration methodology used in an area characterized by IPB Palaeozoic basement, totally covered by tertiary sediments of the Sado Basin. 
This geological scenario is similar to other potential areas like Lagoa Salgada in Portugal and Las Cruces in Spain, where pyrite ores were discovered under tertiary sediments (Oliveira et al. 1998a, b, 2001). At Figueira dos Cavaleiros IPB sector different Bouguer anomaly targets were considered, identified by prior IGM Portuguese Geological Survey surveys (Sousa 1997).

The study area was also airborne surveyed by Rio Tinto Company in 1991, using magnetic and radiometric (U, Th, K, and Total Count) methods. The main gravity/magnetic targets were the Monte Branco, Lameira and Broeira anomalies, located westward of Figueira de Cavaleiros, Portugal (see Fig. 1). The first two anomalies were investigated by mechanic boreholes respectively by Rio Tinto and by IGM. The data obtained by these holes were not conclusive and exploration perspectives were expected to the area. In order to reduce the ambiguity of gravimetric modelling and confirm the geological models established for the region, three P-wave seismic reflection profiles with a total length of about 4 kilometres were acquired (two in Lameira and one in Broeira), processed and interpreted with the aid of two available geological well logs.

\section{Method}

The modelling was performed with commercial software (GMSYS, 2001) which uses the Talwani et al. (1959) algorithm that is based on the assumption that structures are infinite perpendicular to the model. The depth to the top of Palaeozoic rocks was estimated from seismic and well data and density values from Palaeozoic units obtained from several wells in the IPB were then used in the modelling. This density values and corresponding geological units are presented in Table 1 as well as the density values also obtained in the Cenozoic formations. Table 1 also shows intervals velocities derived from stacking velocities obtained during the processing of the seismic reflection data.

A reasonable correlation between densities and lithologies obtained from borehole data and interval velocities from seismic data was achieved (Table 1). Since no velocity logs or check-shots were acquired at the wells, time to depth conversion of the seismic profiles was produced with interval velocities obtained from RMS stacking velocities. The errors in depth estimations at the wells were below $20 \%$.

The structural model produced from seismic and well data is in agreement with the geological models previously established for the area. The significant density contrast between tertiary cover and Palaeozoic basement rocks, permit the identification of the fault zones by the presence of strong gravimetric gradients. These faults are not represented by geomorphology in the research area, which is characterized by a flat smooth topography.

\begin{tabular}{|c|c|c|c|c|}
\hline Profile/Well & $\begin{array}{c}\text { Model } \\
\text { Layer }\end{array}$ & Corresponding Interpreted Geological Unit & $\begin{array}{c}\text { Average Density } \\
(\mathrm{g} / \mathrm{cm} 3)\end{array}$ & $\begin{array}{c}\text { P-wave velocities } \\
(\mathrm{m} / \mathrm{s})\end{array}$ \\
\hline Broeira & $\mathrm{C}$ & Undifferentiated Cenozoic & 2.2 & $1100-2000$ \\
\hline Broeira & $\mathrm{P}$ & Palaeozoic (schists and greywackes) & 2.7 & $2000-3000$ \\
\hline Lameira & $\mathrm{C} 1$ & Neogene (predominantly sandy) & 2.0 & $600-1800$ \\
\hline Lameira & $\mathrm{C} 2$ & Neogene (predominantly sandy) & 2.1 & $1400-2200$ \\
\hline Lameira & C3 & Paleogene conglomerates & 2.3 & $2300-2600$ \\
\hline Lameira & P1 & Weathered Palaeozoic rocks & 2.67 & $2100-3000$ \\
\hline Lameira & P2 & Palaeozoic rocks (schist, greywackes and & 2.82 & $2100-3000$ \\
& & dacites) & 2.57 & - \\
\hline M Branco & - & Palaeozoic (weathered Dacites) & 2.86 & - \\
\hline M Branco & - & Palaeozoic (Dacites) & 2.73 & - \\
\hline LAM1 & - & Palaeozoic (weathered shales) & 2.82 & - \\
\hline LAM1 & - & Palaeozoic (shales) & & \\
\hline
\end{tabular}

Table 1 Densities used in the gravimetric modelling of the Broeira and Lameira profiles and P-wave interval velocities obtained from velocity analysis of reflection data. Also shown are the density values determined in Monte Branco (MBranco) and Lameira wells (LM1). 
Three layers of slightly different densities that correspond to Cenozoic units were used in the modelling. The difference in density of the two upper most ones is probably due to an increase in compaction and different nature of the sediments; since the uppermost $(\mathrm{C} 1)$ is predominantly sandy and the lower one (C2) is more argillaceous. The deepest layer is probably a conglomerate unit of Palaeogene age. The variations of the topography of the top of the Palaeozoic were held constant in accordance with seismic interpretation but its depth was allowed to vary a little since an accurate well-seismic tie was not achieved. A weathered layer of the Palaeozoic shale's basement, observed in the Lameira boreholes, was introduced in the modelling.

A good fit between the calculated and observed gravity field was achieved using density values for the Palaeozoic units usually found for metamorphic rocks such as schists and greywackes. In some part of the profiles higher density values correspondent to igneous units had to be introduced at the top of the Palaeozoic as suggested by the Monte Branco borehole, but no values corresponding to massive sulphide deposits were introduced. The fit between observed and calculated gravity field was particularly good for the Broeira profile, which presents a lower relief of the top of Palaeozoic interface.

\section{Conclusions}

Integrated analysis of geophysical (gravimetric and seismic), borehole and regional geological data preseneted in this work suggest that the probable origin of the Bouguer anomaly of Lameira is the structural imprint of the Grândola fault in the Sado Cenozoic Basin and South Portuguese Paleozoic basement. The Bouguer anomaly map is compatible with the hypothesis of the presence of a paleohorst limited by paleochannels at the east and west and by the Grândola fault to the north, formed during the Alpine tectonic event. Seismic data reinforces this hypothesis. The southern gradient of the anomaly also suggests a fault control, though with a reduced expression. This gradient reflects a larger development of the basin to the south (Alto Sado sector). With regard to the probable occurrence of sulphide ores in Lameira, preliminary data analysis presented in this work does not anticipate an optimistic conclusion due to the nature of the geological formations intersected by the LM1 and LM2 boreholes (barren sedimentary unit). Drillhole LM1 crossed sediments of the PhylliteQuartzite Group until 517,5 m depth. This formation corresponds to the detritic basement of the IPB Volcano-Sedimentary Complex and therefore is not favourable to the occurrence of massive ore deposits. The eventual presence of massive ore deposits would have to be located at depths greater than $550 \mathrm{~m}$ in the Lameira sector in order to explain the borehole data, with no direct influence in the gravimetric field, which signature is compatible with a regional horst structure.

\section{Acknowledgements}

The authors would like to thank MAEPA Company Eng. Adriano Barros Chairman for allowing publication of seismic, gravimetric and magnetic data, and to the Laboratório Nacional de Energia e Geologia field team: J. Leote, J. Marquilhas, J. Gomes, J. Santana, J. Ricardo, M. Silva and F. Caneiras.

\section{References}

Carvalho, D.; Barriga, F.J.A.S.; Munhá, J. [1999] Bimodal-siliciclastic systems - the case of the Iberian Pyrite Belt. Reviews in Economic Geology, 8, 375-408.

GMSYS [2001] In: GMSYS Users Manual, Northwest Geophysical Associates Inc., Oregon, p. 100 Version 3.0.

Oliveira, J.T.; Relvas, J.M.R.S.; Pereira, Z.; Matos, J.X.; Rosa, C.J.; Rosa, D.; Munhá, J.M.; Jorge,R.C.G.S.; Pinto, A.M.M. [2006 ${ }^{a}$ O Complexo Vulcano-Sedimentar da Faixa Piritosa: estratigrafia, vulcanismo, mineralizações associadas e evolução tectono-estratigráfica no contexto da Zona Sul Portuguesa. in Dias R, Araújo A., Terrinha P, e Kulberg JC ( eds.), Geologia de Portugal no contexto da Ibéria, VII Cong. Nac. Geologia, Univ. Évora, Portugal. 
Oliveira, J. T., Pereira, Z., Rosa, C. J., Rosa, D., Matos J. X. [2005] Recent advances in the study of the stratigraphy and magmatismo f the Iberian Pyrite Belt, Portugal. In: Carosi, R., Dias, R., Iacopini, D., Rosenbaum, G. (eds) The southern Variscan Belt. J Virtual Explorer, Electronics Edition 19/9:1441-8142.

Oliveira, V.M.J.; Matos, J.X.; Rosa, C. [2001] The NNW sector of the Iberian Pyrite Belt - new exploration perspectives for the next decade. Geode Workshop - Massive sulphide deposits in the Iberian Pyrite Belt: new advances and comparison with equivalent systems, Aracena Spain.

Oliveira, V., Matos, J.X., Bengala, M., Silva, N., Sousa, P. e Torres, L. [1998a] Geology and Geophysics as Successful Tools in the Discovery of the Lagoa Salgada Orebody (Sado Tertiary Basin - Iberian Pyrite Belt), Grândola, Portugal. Rev. Mineralium Deposita, 33, 170-187.

Oliveira, V.; Matos, J.X.; Bengala, M.; Sousa, P. [1998b] Principais alinhamentos vulcânicos a norte da Falha de Grândola, sob formações da Bacia Terciária do Sado e sua potencialidade mineira no contexto da Faixa Piritosa Ibérica. Actas $V$ Cong. Nacional de Geologia, Com. IGM T. 84 F. 2, Lisboa, Portugal.

Matos, J.X.; Martins, L. [2006] Reabilitação ambiental de áreas mineiras do sector português da Faixa Piritosa Ibérica: estado da arte e perspectivas futuras. Bol. Geológico y Minero España, 117, 289-304.

Relvas, J.M.R.S.; Barriga, F.J.A.S.; Ferreira, A.; Noiva, P.C.; Pacheco, N.; Barriga, G. [2006] Hydrothermal Alteration and Mineralization in the Neves-Corvo Volcanic-Hosted Massive Sulfide Deposit, Portugal. I. Geology, Mineralogy, and Geochemistry. Economic Geology, 101, 753-790.

Sousa, P. [2007] Estudo integrado da geofísica regional aplicada na área de Ferreira do Alentejo: implicações para a prospecção mineira. Technical Report INETI DPMM.

Talwani, M., Worzel, J.C. \& Landisman, M., [1959] Rapid gravity calculations for two-dimensional bodies with application to the Mendocino submarine fracture zone. J. Geophys. Res., 64, 49-59. 